\title{
Accounting
}

\section{The rule of organizational citizenship behavior and innovative work behavior in mediating the influence of organizational commitment and culture to employee performance}

\author{
Tomy Fitrio ${ }^{a^{*}}$, Budiyanto ${ }^{a}$ and Agustedi $^{a}$
}

\begin{tabular}{l} 
a Sekolah Tinggi Ilmu Ekonomi Indonesic \\
\hline C H R O N I C L E \\
\hline Article history: \\
Received: April 29, 2020 \\
Received in revised format: \\
July 30 2020 \\
Accepted: August 10, 2020 \\
Available online: \\
August 17, 2020 \\
\hline Keywords: \\
Organizational Citizenship \\
Behavior (OCB) \\
Innovative Work Behavior (IWB) \\
Organizational Commitment \\
Organizational Culture \\
Employee Performance
\end{tabular}

\begin{abstract}
A B S T R A C T
The purpose of this study was to determine the rule of organizational citizenship behavior (OCB) and innovative work behavior (IWB) in mediating the influence of organizational commitment and culture to employee performance with Bank Riau Kepri as the research object. Samples in this study were 105 employees of Bank Riau Kepri. Samples were taken using proportional stratified random sampling technique. Data collecting in this study was done using closed-questionnaires as research instrument. Data collected was analyzed using SmartPLS 3.0 program. The results of this study found that: (1) Organizational commitment variable had not influenced to employee performance, (2) Organizational culture variable had influenced to employee performance, (3) OCB fully mediated the influence of organizational commitment to employee performance, and (4) IWB partially mediated the influence of organizational culture to employee performance.
\end{abstract}

\section{Introduction}

Empirical studies conducted by previous researchers reveal that there is an influence of organizational commitment to employee performance (Hafiz, 2017; Memari et al., 2013; Pranita, 2017; Musabah et al., 2017; Shaputra \& Hendriani, 2015, Fitrio et al., 2019). In contrast, other empirical studies found that organizational commitment has no influence to employee performance (Suwibawa et al., 2018; Yiing \& Ahmad, 2009; Sutopo, 2018; Renyut et al., 2017). In other studies, former researchers found that organizational culture influences employee performance (Emeka \& Philemon, 2012; Isa et al., 2016; Muhammad \& Mukzam, 2017; Shahzad, 2014; Valencia et al., 2011; Wagiman, 2018) while other empirical studies reveal that organizational culture is not affecting employee performance in contrast finding (Syauta et al., 2012; Maabuat, 2016; Lembang et al., 2016). Further empirical studies also reveal the influence of organizational commitment to Organizational Citizenship Behavior (OCB) (Sutrisno et al., 2018; Yaseen et al., 2015; Uddin et al., 2018; Ortiz et al., 2015). On the other side, some empirical studies reveal the influence of organizational culture on Innovative Work Behavior (IWB) (Pickled \& Pickled, 2012; Katarzyna, 2015; Laforet, 2016; Taghipour \& Dezpuli, 2013; Valle et al., 2011; Wu et al., 2019). Other empirical studies also reveal the influence of OCB to employee performance (Bagyo, 2018; Chelagat et al., 2015; Gunay, 2018; Pristiyono et al., 2019; Singh et al., 2016; Sugianingrat et al., 2019) while other empirical studies reveal that there is no effect of CB to employee performance (Halim \&

* Corresponding author.

E-mail address: tomy@stieindragiri.ac.id (T. Fitrio) 
Dewi, 2018). Due to IWB, several past studies found that there is an influence of IWB to employee performance (Abdulai et al., 2016; Berliana \& Arsanti, 2018; Cingoz \& Akdogan, 2011; Dama \& Imelda, 2018; Gunday et al., 2011; Nasir et al., 2019; Ornek \& Ayas, 2015). In contrast, other empirical studies reveal that there were mediating effects of OCB parameter toward employee performance (Sari, 2016) and IWB parameter toward employee performance (Valencia et al., 2011).

Based on the results of research that are varied between one to another and different from previous studies, researchers conclude that there is inconsistency of the results of previous researchers. That is the research gap we found about the effects of several variables of organizational commitment, organizational culture, OCB, and IWB to employee performance. Escalated and deepened research needs to be done to find the gap analysis between researchers' finding for the last decade. Referring to the concept of performance and empirical studies conducted by previous researchers, this study examines the concept of employee performance empirically, by taking the object of research is Bank Riau Kepri, and the population is employees of Bank Riau Kepri, the variables that are observed by researchers in this study are organizational commitment, organizational culture, OCB, IWB, and employee performance. Specifically, we elaborate to determine the rule of other mentioned variables to employee performance. The selection of these variables is based on previous research which still shows the gap research and for the solution of the gap the researcher uses a mediation approach, the reason behind the use of the mediation approach is derived from empirical and theoretical studies point-of-view. The researcher suspects that there are other variables that are exclusive and can fill the gap research due to OCB and IWB. It is expected that the mediating variables can be a solution to the gap between endogenous and exogenous variables in this study.

\section{Literature Review and Hypotheses Development}

\subsection{The Influence of Organizational Commitment to Employee Performance}

Meyer and Allen (1997: 11) brought up a model of organizational commitment that consists of three components related to the state of psychology: affective commitment, continuance commitment and normative commitment. Wirawan (2017: 773) then added one more component which is the intermediate commitment or stepping stone commitment. Davis and Newstrom (2001: 211) define organizational commitment as the emotional connection that employees feel with their work, a level of loyalty related to his association with the organization the employee experiences, and the willingness to continue to participate or work with the organization. Franke and Felfe, (2008) state the conceptual framework, antecedents, correlations, and consequences of organizational commitment that: job characteristics, compensation, work climate, leadership, age, education, organizational justice and organizational support are factors that influence organizational commitment. While the factors that are influenced by organizational commitment are: motivation, performance, organizational citizenship behavior, well-being, desire to change, absence, desire to leave, and work stress. Meyer and Allen, (1991) proposed a model of organizational correlation. The organization related to: commitment, job satisfaction, job involvement, and occupational commitment. Affective commitment is related to individual characteristics, work experience, the desire to stop and quit work. Continuance commitment is related to individual characteristics, work alternatives, work behavior, attendance and organizational citizenship behavior. Normative commitment relates to individual characteristics, socialization, experience, organization, investment, employee health and selfwelfare.

$\mathrm{H}_{1}$ : Organizational commitment influences the employee performance.

\subsection{The Influence of Organizational Culture to Employee Performance}

Hofstede (2010: 219) mentions that, "Culture is the programming of the collective mind that distinguishes members of one group or category of people from another". Wirawan (2017:9) defines organizational culture as the norms, values, assumptions, philosophies of organizations developed by leaders organization and applied in the organizational behavior of members of the organization In general, organizational culture is formulated as a vision, mission, strategic objectives, and strategic values, organizational culture is taught to members of the organization and monitored systematically. Meanwhile, Neiva et al. (2015) states that this organizational culture has an impact on employees / workers such as: providing work morale and enjoying the work environment, perceiving individual and group satisfaction, persuading employees to be able to achieve certain levels of performance goals. Cameron and Quiin (2011) have developed special measurement tools to measure organizational culture and are known as OCAI (Organizational Culture Assessment Instrument). The OCAI measuring device consists of 24 question items with 6 indicators. The six indicators are: (1) Dominant Characteristics, (2) Organizational Leadership, (3) Management of Employees, (4) Organization Glue, (5) Strategic Emphases, (6) Criteria of Success. According to Robert and Kinicki (2005: 80) there are several factors that influence organizational culture in a company. The factors are as follows: (1) value, (2) trust, (3) desired behavior, (4) very important circumstances, (5) respective guidelines for selecting or evaluating events, and (6) behavior.

$\mathrm{H}_{2}$ : Organizational culture influences the employee performance. 
Organ (1988: 27) defines OCB as human behavior that is not mandatory for an individual where the formal reward system does not directly or clearly recognize and totally contribute to the organizational effectiveness function. The organ explains what he means by not compulsorily as behavior that is not a written requirement of the role or job description, namely the conditions that have been determined from an individual's employment contract with the organization. Wirawan, (2017: 780) defines OCB is voluntary behavior in the workplace carried out by employees freely that is outside of one's job requirements and organizational requirements so that there is no organizational reward system that if implemented by employees will improve the functioning of the organization. The factors affecting that influence the emergence of OCB are quite complex and interrelated with one another. Among these factors that will be discussed include organizational culture and climate, personality and mood, perceptions of organizational support, perceptions of supervisors, subordinates, years of service and sex (Organ, 1995). Rauf, (2016) states that OCB influences the performance of organizations and individuals both positively or negatively. Organ (1988: 56) suggests five indicators used to measure OCB, namely as follows: (1) Altruism, (2) Consciousness, (3) Sportmanship, (4) Civic Virtue, and (5) Courtessy.

$\mathrm{H}_{3}$ : Organizational Citizenship Behavior (OCB) mediates the influence of organizational commitment to employee performance.

Innovative Work Behavior (IWB) in Mediating the Influence of Organizational Ethic to Employee Performance

Hurley and Hult (1998) state that innovation can be seen as the extent to which an organization produces, receives and implements new ideas, processes, products, or services. The Indonesian Dictionary or Kamus Besar Bahasa Indonesia (KKBI) defines innovation as new discoveries that are different from those that has already existed or that have been known before (ideas, methods, or tools) (http://kbbi.web.id/). Damanpour (2010) argues that organizations innovate regularly because of pressure from the external environment, such as competition, deregulation, isomorphism, scarcity of resources, and customer demand, or because of internal organizational choices, such as gaining different competencies, achieving higher levels of aspirations, and increasing range and quality of service. Pervaiz (2010) states that corporate innovation can produce R\&D (Research and Development), production renewal, and marketing approaches. It ultimately leads to the commercialization of the innovations. In other words, innovation is the process of realizing new ideas, which are different from the past, by means of production or by making it become evident, where innovation includes generation of evaluations, new concepts and implementations, use of new and different methods and technologies to improve quality or lower costs, to meet or exceed company targets. Yuan and Woodman (2010) describe factors that influence innovative work behavior, namely: (1) organizational culture and climate, (2) relationships with supervisors, (3) job characteristics, (4) social / group context, and (5) individual differences. According to Stoffers, (2009) IWB affects the objective organizational performance and perceived organizational performance. Jong and Hartog (2010) say that IWB is a form of behavior that aims to achieve the initiation and introduction of an idea, process, procedure or new product that is useful for organizations in this research is the company. According to Jong and Hartog (2010) there are 4 (four) indicators to measure innovative work behavior, namely: (1) Idea Exploration, (2) Idea Generation, (3) Idea Championing, and (4) Idea Implementation.

$\mathrm{H}_{4}$ : Innovative Work Behavior (IWB) mediates the influence of organizational culture to employee performance.

\subsection{Previous Research}

Previous research related to the rule of OCB and IWB in mediating the influence of organizational commitment and culture to employee performance can be seen in Table 1.

\section{Table 1}

Previous research related to the rule of OCB and IWB in mediating the influence of organizational commitment and culture to employee performance

\begin{tabular}{|c|c|c|c|c|}
\hline No. & Researchers & Year & Variables & Findings \\
\hline 1 & Sutrisno et al. & 2018 & $\begin{array}{c}\text { KO-OCB } \\
\text { KO- OCB-KK }\end{array}$ & $\begin{array}{c}\text { There is an influence } \\
\text { OCB mediates KO-KK }\end{array}$ \\
\hline 2 & Uddin et al. & 2018 & KO-OCB & There is an influence \\
\hline 3 & Yaseen et al. & 2015 & $\mathrm{KO}-\mathrm{OCB}$ & There is an influence \\
\hline 4 & Ortiz et al. & 2015 & $\mathrm{KO}-\mathrm{OCB}$ & There is an influence \\
\hline 5 & Bagyo & 2018 & OCB-KK & There is an influence \\
\hline 6 & Chelagat et al. & 2015 & OCB-KK & There is an influence \\
\hline 7 & Gunay & 2018 & OCB-KK & There is an influence \\
\hline 8 & Singh et al. & 2016 & OCB-KK & There is an influence \\
\hline 9 & Sari & 2016 & BO-OCB-KK & OCB mediates BO-KK \\
\hline 10 & Sugianingrat & 2019 & OCB-KK & There is an influence \\
\hline 11 & Pristiyono & 2019 & OCB-KK & There is an influence \\
\hline
\end{tabular}


1354

\begin{tabular}{|c|c|c|c|c|}
\hline 12 & Emeka and Philemon & 2012 & BO-KK & There is an influence \\
\hline 13 & Muhammad and Mukzam & 2017 & BO-KK & There is an influence \\
\hline 14 & Valencia et al. & 2011 & BO-Innovation-KK & Innovation mediates BO-KK \\
\hline 15 & Wagiman & 2018 & BO-KK & There is an influence \\
\hline 16 & Isa et al. & 2016 & BO-KK & There is an influence \\
\hline 17 & Shahzad & 2014 & BO-KK & There is an influence \\
\hline 18 & Nasir et al. & 2019 & IWB-KK & There is an influence \\
\hline 19 & Berliana and Arsanti & 2018 & IWB-KK & There is an influence \\
\hline 20 & Cingoz and Akdogan & 2011 & IWB- Performance & There is an influence \\
\hline 21 & Dama and Ogi & 2018 & Innovation -KK & There is an influence \\
\hline 22 & Gunday et al. & 2011 & Innovation -Performance & There is an influence \\
\hline 23 & Ornek and Ayas & 2015 & IWB-Performance & There is an influence \\
\hline 24 & Acar and Acar & 2012 & BO-Innovation & There is an influence \\
\hline 25 & Katarzyna & 2015 & BO-Innovation & There is an influence \\
\hline 26 & Laforet & 2016 & BO-Innovation & There is an influence \\
\hline 27 & Taghipour and Dezfuli & 2013 & BO-Innovation & There is an influence \\
\hline 28 & Valle et al. & 2011 & BO-Innovation & There is an influence \\
\hline 29 & Wu et al. & 2019 & BO-Innovation & There is an influence \\
\hline 30 & Hafiz & 2017 & KO-KK & There is an influence \\
\hline 31 & Memari et al. & 2013 & KO-KK & There is an influence \\
\hline 32 & Musabah et al. & 2017 & KO-KK & There is an influence \\
\hline 33 & Pranita & 2017 & KO-KK & There is an influence \\
\hline 34 & Shaputra and Hendriani & 2015 & KO-KK & There is an influence \\
\hline 35 & Purba & 2009 & BO-IWB-KK & There is an influence \\
\hline 36 & Rahayu & 2017 & KK-OCB-KK & There is an influence \\
\hline 37 & Suprianto & 2014 & KO-OCB-KK & OCB mediates KO-KK \\
\hline 38 & Suwibawa et al. & 2018 & KO-KK & There is no influence \\
\hline 39 & Yiing and Ahmad & 2009 & KO-KK & There is no influence \\
\hline 40 & Sutopo & 2018 & KO-KK & There is no influence \\
\hline 41 & Renyut et al. & 2017 & KO-KK & There is no influence \\
\hline 42 & Halim and Dewi & 2018 & OCB-KK & There is no influence \\
\hline 43 & Syauta et al. & 2012 & BO-KK & There is no influence \\
\hline 44 & Maabuat & 2016 & BO-KK & There is no influence \\
\hline 45 & Lembang et al. & 2015 & BO-KK & There is no influence \\
\hline
\end{tabular}

Source: data accessed and summarized by the researchers from literature studies.

\subsection{Stating the Research Problems}

The research problems in this study are defined as follows:

- Does organizational commitment influence the performance of Bank Riau Kepri employees?

- Does organizational culture influence the performance of Bank Riau Kepri employees?

- Does OCB mediate the influence of organizational commitment on the performance of Bank Riau Kepri employees?

- Does IWB mediate the influence of organizational culture on the performance of Bank Riau Kepri employees?

\subsection{Conceptual Framework}

The conceptual framework in this study can be seen in Fig. 1.

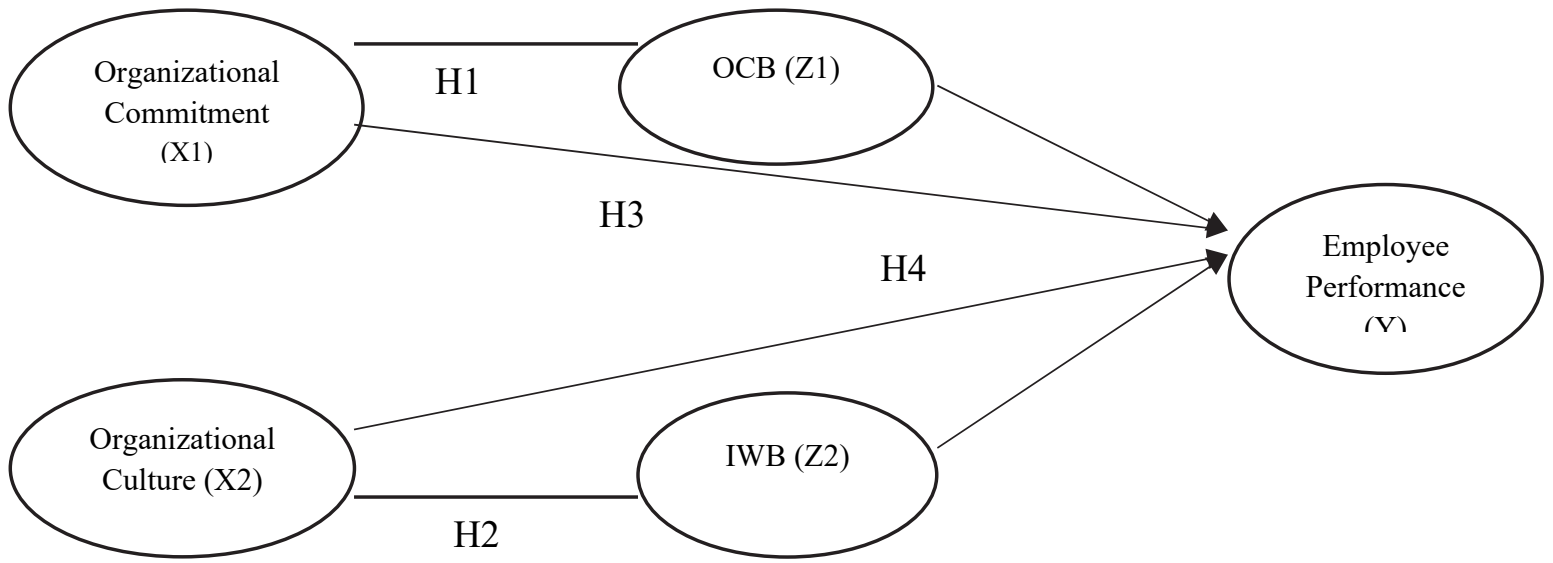

Fig. 1. Conceptual Framework 


\section{Research Methodology}

This research is a quantitative research under a positivistic approach using descriptive quantitative methods. Creswell (2008: 5) says that quantitative research is a method for testing certain theories by examining the relationships between variables, including independent, dependent, and intervening variables. The population of this study was 1050 people. Arifin (2011: 224) states that if the population members are above 1000, then the sample can be taken $10-15 \%$ of the total amount of expected objects. In this study, the researchers took a sample of $10 \%$ of the population that is 105 people. The stratified proportional random sampling method was chosen as sampling technique. The questionnaire was tested to determine the validity and reliability using the help of IBM SPSS 24 application while the hypothesis was tested using the help of SMARTPLS 3.0 application. Organizational Commitment Indicators were developed from Allen and Meyer (1991) and Steers and Porter (1974), consisting of: Affective commitment, Continuance commitment, and Normative commitment. Organizational Culture Indicators were developed from Cameron and Quinn (2011) and Denison (2012), consisting of: Dominant characteristics, Organizational leadership, Management of employees, Organization glue, Strategic emphases, and Criteria of success. Organizational Citizenship Behavior (OCB) Indicators were developed from Organ (1988) and Podsakoff et al. (2000), consisting of: Alturism, Consciousness, Sportmanship, Civic virtue, and Courtessy. Innovative Work Behavior (IWB) Indicators were developed from Jong and Hartog (2010), consisting of: Idea Exploration, Idea Generation, Idea Championing, and Idea Implementation. Employee Performance Indicators were developed from Mathis and Jackson (2011) and Tsui (1997), consisting of: Quantity of results, Quality of results, and Attendance / Punctuality.

\section{Empirical Results and Discussions}

\subsection{Instrument Testing}

If the correlation coefficient ( $\mathrm{r}$ count) $\geq 0.3$, it can be concluded that the statement items are valid. Meanwhile, if the correlation coefficient ( $\mathrm{r}$ count) $\leq 0.3$, then it can be concluded that the statement items are invalid (Sugiyono 2016: 183). From the test results all statement items have a correlation coefficient value $\geq 0.3$, so it can be concluded that all statement items are valid. Variables are declared reliable if the Cronbach Alpha coefficient value $>0.60$, it means that the reliability level of 0.60 is a reliable indication of a construct (Sugiyono 2016: 184). From the test results all Cronbach Alpha values $>0.6$. This means that each questionnaire statement item from each variable is able to form the construct of the variable. Thus, the list of statements of all questionnaires is reliable to measure each variable.

\subsection{Analysis of Measurement Model (Outer Model)}

\section{Validity Test}

The results of construct validity testing can be seen in Fig. 2 .

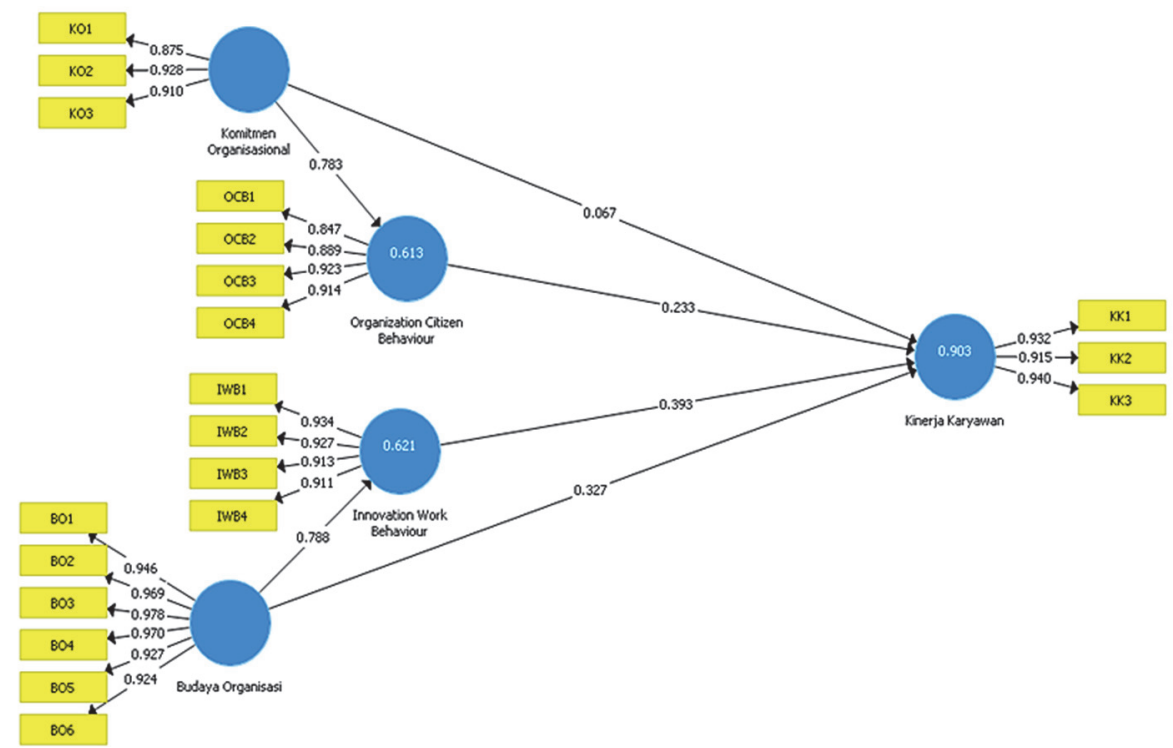

Fig. 2. Validity Testing 
A loading value of 0.7 or more is considered very satisfactory (Henseler et al., 2009; Gotz et al., 2010) while indicators that have a loading factor value of 0.5 are considered acceptable and indicators with a loading factor value of less than 0.5 must be excluded (Chin, 1995; Hair et al., 2010). From Fig. 2 it can be seen that all factor loading values are greater than 0.7 meaning that all indicators on the research variables are valid.

\subsection{Reliability Test}

The results of construct validity testing can be seen in Table 2 .

Table 2

Reliability Test

\begin{tabular}{|c|c|c|}
\hline Variable & Cronbach Alpha & Composite Reliability \\
\hline Organizational Commitment $\left(\mathrm{X}_{1}\right)$ & 0.889 & 0.931 \\
\hline Organizational Culture $\left(\mathrm{X}_{2}\right)$ & 0.979 & 0.983 \\
\hline Organizational Citizenship Behavior (OCB) $\left(\mathrm{X}_{3}\right)$ & 0.916 & 0.941 \\
\hline Innovative Work Behavior (IWB) $\left(\mathrm{X}_{4}\right)$ & 0.941 & 0.957 \\
\hline Employee Performance (Y) & 0.921 & 0.950 \\
\hline
\end{tabular}

Source: data analysis results from SmartPLS application.

Reliability testing in PLS can be done using two methods, namely Cronbach Alpha and composite reliability. Cronbach Alpha measures the lower limit of reliability while composite reliability measures the true value of the reliability of a construct (Chin, 1995). Composite reliability is considered better in estimating the internal consistency of a construct (Werst et al., 1974). Rule of thumb value of Cronbach Alpha and composite reliability must be greater than 0.70 although the value of 0.60 is still acceptable (Hair et al, 2006). From Table 2 we can see that Cronbach Alpha and composite reliability are greater than 0.70. This means that the construct validity parameter was gained and the research model consists of organizational commitment, organizational culture, OCB, IWB, and employee performance. It can also be said that the instrument was reliable to be used.

\subsection{Analysis of Structural Model (Inner Model)}

Analysis of Determinacy Coefficient (R-Square)

Table 3 shows the results of analysis of determinacy coefficient or R-Square.

Table 3

R-Square Scores

\begin{tabular}{lc}
\hline Variable & R Square \\
\hline Organizational Commitment (X1) & - \\
Organizational Culture (X2) & 0.613 \\
Organizational Citizenship Behavior (OCB) (X3) & 0.621 \\
Innovative Work Behavior (IWB) (X4) & 0.903 \\
Employee Performance (Y) & \\
\hline
\end{tabular}

Source: data analysis results from SmartPLS application.

$\mathrm{R}^{2}$ results of $0.67,0.33$ and 0.19 for endogenous variables in the structural models indicate that the models fit the category of "good", "moderate" and "weak" respectively (Ghozali, 2014). Goodness of fit on the model using SmartPLS can be obtained from the $\mathrm{R}^{2}$. The higher the $\mathrm{R}^{2}$ then the more the model can be accepted increasingly or it can be said that the model is suitable and fit. The calculation results of $\mathrm{R}^{2}$ to employee performance variable show the value of 0.903 and it is more than 0.67 . It means that the model is fit. The range variations from research data can be defined by structural models and have values that are relevant to higher values.

\subsection{Hypotheses Testing Results}

Table 4 shows the results of hypotheses testing in this study. Abdillah and Jogiyanto (2015: 197) stated that the path coefficient score or the inner model shown by the statistical T value must be higher 1.96 for hypothesis testing at significant value level or alpha $(\alpha)$ of $5 \%$ percent.

\section{H1: Organizational Commitment Influences the Employee Performance.}

The influence of organizational commitment variable to employee performance variable is 0.067 with a t-statistics value of 0.796 , where the t-statistics value is smaller than 1.96 . So, it can be concluded that the organizational commitment variable has no influence to employee performance variable. This means that regardless of organizational commitment increase, there will no improvement in employee performance at Bank Riau Kepri. Thus, the first hypothesis stating that organizational commitment influences the employee performance at Bank Riau Kepri is rejected $\left(\mathrm{H}_{1}\right.$ is rejected). 
Hypotheses Testing

\begin{tabular}{lccc}
\multicolumn{1}{c}{ Influence Between Variables } & Original Sample (O) & $\begin{array}{c}\text { T Statistics } \\
(\text { O/STDEV) }\end{array}$ & Findings \\
\hline $\begin{array}{l}\text { Organizational Commitment }\left(\mathrm{X}_{1}\right) \rightarrow \text { Employee } \\
\text { Performance }(\mathrm{Y})\end{array}$ & 0.067 & 0.796 & There is no influence \\
\hline $\begin{array}{l}\text { Organizational Culture }\left(\mathrm{X}_{2}\right) \rightarrow \text { Employee Performance } \\
(\mathrm{Y})\end{array}$ & 0.327 & 3.356 & There is an influence \\
\hline $\begin{array}{l}\text { Organizational Commitment }\left(\mathrm{X}_{1}\right) \rightarrow \text { Organizational } \\
\begin{array}{l}\text { Citizenship Behavior }(\mathrm{OCB})\left(\mathrm{X}_{3}\right) \rightarrow \text { Employee } \\
\text { Performance }(\mathrm{Y})\end{array}\end{array}$ & 0.182 & 2.191 & There is an influence \\
\hline $\begin{array}{l}\text { Organizational Culture }\left(\mathrm{X}_{2}\right) \rightarrow \text { Innovative Work Behavior } \\
(\mathrm{IWB})\left(\mathrm{X}_{4}\right) \rightarrow \text { Employee Performance }(\mathrm{Y})\end{array}$ & 0.309 & 5.001 & There is an influence \\
\hline
\end{tabular}

Source: data analysis results from SmartPLS application.

$\mathbf{H}_{2}$ : Organizational Culture Influences the Employee Performance.

The influence of organizational culture variable to employee performance variable is 0.327 with a t-statistics value of 3.356 , where the t-statistics value is greater than 1.96. So, it can be concluded that organizational culture variable has an influence to employee performance variable. This means that if organizational culture is improved, there will be also an improvement in employee performance. Thus, the second hypothesis stating that organizational culture influences the employee performance at Bank Riau Kepri is accepted ( $\mathrm{H}_{2}$ is accepted).

H3: Organizational Citizenship Behavior (OCB) Mediates the Influence of Organizational Commitment to Employee Performance.

The influence of organizational commitment variable on employee performance through OCB variable is 0.182 with a t-statistics value of 2.191, where the t-statistics value is greater than 1.96. So, it can be concluded that the organizational commitment variable has an influence to employee performance variable through OCB variable. This means that if OCB is improved, it will lead to the improvement in employee performance. Thus, the third hypothesis stating that OCB mediates the influence of organizational commitment to employee performance at Bank Riau Kepri is accepted $\left(\mathrm{H}_{3}\right.$ is accepted).

H4: Innovative Work Behavior (IWB) Mediates the Influence of Organizational Culture to Employee Performance.

The influence of organizational culture variable on employee performance variable through IWB variable is 0.309 with a tstatistics value of 5.001, where the t-statistics value is greater than 1.96. So, it can be concluded that the organizational culture variable has an influence to employee performance variable through IWB variable. This means that if the IWB is improved, it will lead to the improvement in employee performance. Thus, the fourth hypothesis stating that IWB mediates the influence of organizational cultural to employee performance at Bank Riau Kepri is accepted ( $\mathrm{H}_{4}$ is accepted).

\section{Discussion}

Hypotheses test results conducted indicate that organizational commitment does not significantly influence employee performance. This is in line with research by Suwibawa et al. (2018) which states that organizational commitment has no effect on the performance of Bappeda R\&D staff in the Province of Bali; Yiing and Ahmad, (2009) who stated that organizational commitment had no effect on the performance of MBA part time student employees in Malaysia; Sutopo (2018) who stated that organizational commitment has no effect on the performance of employees of the education department's financial staff in Klaten; and Renyut et al. (2017) research which shows that organizational commitment does not have a significant effect on employee performance in the Maluku governor's office. In contrary, the results of the hypotheses test conducted also show that organizational culture has a significant influence to employee performance. This is in line with the results of research by Emeka and Philemon, (2012) which states that organizational culture influences employee performance in the manufacturing industry in Enugu; Muhammad and Mukzam, (2017) who stated that organizational culture influences the performance of employees of BRI Bank in Tuban Branch; Wagiman, (2018) who stated that organizational culture influences the performance of employees of BRI Regional Office in Semarang; Isa et al., (2016) which states that organizational culture influences the performance of employees of public sector organizations in Oman; and Shahzad (2014) research which shows that organizational culture influences the performance of software house employees in Pakistan. The results of the hypotheses test conducted show that organizational commitment significantly influences employee performance through the OCB variable or it can be said that OCB mediates the influence of organizational commitment to employee performance. This is in line with research of Sutrisno et al. (2018) that shows OCB mediates the effect of organizational commitment on the performance of employees of PT Fumira Semarang; Suprianto, (2014) who shows that organizational citizenship behavior mediates the effect of organizational commitment on the performance of employees of PT Dan Liris Sukoharjo; and Rahayu (2017) who finds that OCB mediates the effect of organizational commitment on the performance of medical employees at Fathma Medika Gresik Hospital. 
The results of the hypotheses test conducted show that organizational culture significantly influences employee performance through the IWB variable or it can be said that IWB mediates the influence organizational culture to employee performance. This is in line with Purba's research (2009) which shows that innovative work behavior mediates the influence of organizational culture variables on the performance variables of department leaders at Medan State University; the research of Valencia et al. (2011) where innovation mediates the influence of organizational culture variables on employee performance variables in companies in Spain; and Nasir et al. (2019) who states that the innovative work behavior mediates the effect of organizational culture variables on the performance variables of state tertiary lecturers. After seeing the mediation variables used, namely OCB and IWB, it can be proven that both variables have a role in improving employee performance at Bank Riau Kepri. Researchers have innovative ideas that can be tested by combining the variables of OCB and IWB into a new variable called Innovative Citizenship Behavior (ICB). This idea was emerged from the results of the study known that the highest value indicator on OCB is altruism and the lowest value indicator of IWB is exploration ideas, meaning that if the exploration of these ideas combined with altruism, then the results will produce an innovative concept of citizenship behavior, with the following dimensions: (1) Innovative Altruism, (2) Innovative Consciousness, (3) Innovative Sportmanship, (4) Innovative Civic Virtue, (5) Innovative Courtessy. This new concept needs to be tested empirically.

\section{Conclusions and Implications}

Based on the results of the research and discussion in the previous chapter, the several conclusions can be drawn to answer the research questions as follows:

a. The variable of organizational commitment does not significantly influence employee performance at Bank Riau Kepri. This means that the hypothesis stating that organizational commitment influences the employee performance at Bank Riau Kepri is rejected.

b. The variable of organizational culture significantly influences employee performance at Bank Riau Kepri. This means that the hypothesis stating that organizational culture influences the employee performance at Bank Riau Kepri is accepted.

c. The variable of OCB fully mediates the influence of organizational commitment on employee performance. This means that the hypothesis stating that OCB mediates the influence of organizational commitment to employee performance at Bank Riau Kepri is accepted.

d. The variable of IWB partially mediates some of the effects of organizational culture on employee performance. This means that the hypothesis stating that IWB mediates the influence of organizational cultural to employee performance at Bank Riau Kepri is accepted.

This study only discusses the variables of organizational commitment, organizational culture, OCB and IWB that affect employee performance. This study only explains the role of OCB and IWB as mediating variables. In the future if organizational culture variables are used as mediating variables between OCB or IWB toward employee performance, it may provide new escalation scope and sequence for research results in the field of employee performance.

\section{References}

Abdillah. W, \& Jogiyanto. (2015). Partial Least Square (PLS) Alternatif Structural Equation Modeling (SEM) dalam Penelitian Bisnis. Ed 1. ANDI.Yogyakarta.

Acar. A. Z, \& P. Acar. (2012). The effects of organizational culture and innovativeness on business performance in healthcare industry. Procedia - Social and Behavioral Sciences 58, $683-692$.

Arifin. Z. (2011). Metode Penelitian Kualitatif, Kuantitatif, \& $R \& D$. Edisi 8. Alfabeta. Bandung.

Bagyo. Y. (2018). The effect of counterproductive work behaviour (CWB) and organization citizenship behaviour (OCB) on employee performance with employee engagement as intervening variable. IOSR Journal of Business and Management, 20(2), 83-89.

Bahri. S, \& Zamzam, F. (2015). Model Penelitian Kuantitatif Berbasis SEM-AMOS. Edisi 2. Deepublish.Yogyakarta.

Berliana, V., \& Arsanti, T. A. (2018). Analisis Pengaruh Self Eficacy, \& Perilaku Kerja Innovatif Terhadap Kinerja. Jurnal Maksipreneur $7(2), 149-161$.

Cameron. K. S., \& Quinn, R. E. (2011). Diagnosing and Changing Organizational Culture: Based on the Competing Values Framework. 3 rd. ed. The Jossey-Bass Business \& Management. San Francisco.

Chelagat. L. J, C. P. Kiprop, \& A. Kemboy. (2015). Effect of Organizational Citizenship Behavior on Employee Performance in Banking Sector, Nairobi County, Kenya. International Journal of Business, Humanities and Technology, 5(4), 55-61.

Chin, W. W. (1995). Partial least squares is to LISREL as principal components analysis is to common factor analysis. Technology Studies, 2(2), 315-319.

Cingöz, A., \& Akdoğan, A. A. (2011). An empirical examination of performance and image outcome expectation as determinants of innovative behavior in the workplace. Procedia-Social and Behavioral Sciences, 24, 847-853.

Dama. J. I, \& W. J. Oriz. (2018). Pengaruh Inovasi dan Kreativitas terhadap Kinerja Karyawan pada PT Bank Mandiri (Persero) Tbk. Manado. Jurnal EMBA 6(1), 41-50.

Damanpour. F. (2010). An integration of research findings of effects of firm Size and market competition on product and process innovation. British Journal of Management, 21(4), 996-1010). 
Denison. D. R. (2012). Corporate Culture and Organizational Effectiveness $1^{\text {th }}$ edition. Denison Consulting. Michigan.

Emeka. N, \& A. Philemon. (2012). The impact of organizational culture on employee performance: A study of selected manufacturing industry in Enugu. Asian Journal of Business Management Studies, 3(2),13-19.

Fitrio, T., Apriansyah, R., Utami, S., \& Yaspita, H. (2019). The effect of job satisfaction to organizational citizenship behavior (OCB) mediated by organizational commitment. International Journal of Scientific Research and Management, 7(9).

Franke, F., \& Felfe, J. (2008). Commitment und Identifikation in Organisationen: Ein empirischer Vergleich beider Konzepte. Zeitschrift für

Arbeits-und Organisationspsychologie A\&O, 52(3), 135-146.

Ghozali, I. (2014). Structural Equation Modeling: Teori, Konsep, \& Aplikasi dengan Program Lisrel 8.54. Edisi 2. Badan Penerbit UNDIP. Semarang.

Götz. D. (2010). Langenscheidt Grosswörterbuch. Langenscheidt KG. München.

Gunay, G. Y. (2018). Relationship Between Job Satisfaction, Organizational Citizenship Behaviour, and Employee Performance: Sample Edirne Financial Office Employee in Turkey. American International Journal of Contemporary Research, 8(1),64-65.

Gunday, G., Ulusoy, G., Kilic, K., \& Alpkan, K. L. (2011). Effects of innovation types on firm performance. International Journal of Production Economics 133(2), 662-676.

Hafiz. A. Z. (2017). Relationship between organizational commitment and employee performance evidence from banking sector of lahore. Arabian Journal of Business and Management Review 7(2),1-7.

Hair. J. F, Black, W.C., Babin, B.J., \& Anderson, R.E. (2010). Multivariate data analysis. 7th ed. Pearson Prentice Hall. New Jersey.

Halim, A. N., \& Dewi, M. B. (2018). Analisa Pengaruh Organizational Citizenship Behavior Terhadap Kinerja Karyawan Hotel Bintang 3 Di Surabaya. Jurnal Hospitality dan Manajemen Jasa, 6(2), 183-196.

Henseler, J., Ringle, C. M., \& Sinkovics, R. R. (2009). The use of partial least squares path modeling in international marketing. Advances in International Marketing, 20(1), 277-319.

Hofstede, G. J. (2010). Measuring Organizational Cultures: A Qualitative and Quantitative Study Across Twenty Cases. $2^{\text {Th }}$ Edition. Administrative Science Quarterly. New York.

https://kbbi.web.id/inovasi

Hurley, R. F., \& Hult, G. T. M. (1998). Innovation, market orientation, and organizational learning. An Integration and Empirical Examination, Journal of Marketing, 62(3), 42-54.

Isa, M. F. M., Ugheoke, S. O., \& Noor, W. S. W. M. (2016). The influence of organizational culture on employees' performance: evidence from Oman. Journal of Entrepreneurship and Business, 4(2), 1-12.

Jong, D. J., \& Hartog, D. (2010). Measuring Innovative Work Behavior. Creativity and Innovation Management, 19(1), 23-36.

Katarzyna, S. W. (2015). Leadership and organizational culture as the normative influence of top management on employee's behaviour in the innovation process. Procedia Economics and Finance, 34(1), 396-402.

Laforet, S. (2016). Effects of organisational culture on organisational innovation performance in family firms. Journal of Small Business and Entreprise Development, 23(2), 379-407.

Lembang, A. K, Soecipto, B. E., \& Sutrisno. (2015). The effect of transformational leadership and organizational culture on employee's working performance through organizational commitment. I J A B E R, 13(7), 5305-5322.

Maabuat. E. S. (2016). Pengaruh Kepemimpinan, Orientasi Kerja, \& Budaya Organisasi Terhadap Kinerja Pegawai (Studi Pada Dispenda Sulut UPTD Tondano). Jurnal Berkala Ilmiah Efisiensi, 16(01), 219-231.

Mathis, L. R., \& Jackson, J. H. (2009). Human Resource Management. Mason. OH. USA. Terjemahan. (2011). Human Resource Management, (edisi 10). Salemba Empat. Jakarta.

Memari, N, Mahdieh, O., \& Marnani, A. B. (2013). The impact of organizational commitment on employees job performance: A Studi of Meli Bank. Interdisiplinary Journal of Contemporary Research and Business 5(5), 164-171.

Meyer, J. P., Allen, N.J. (1991). A three component conceptualization of organizational commitment. Human Resources Management Review, 1(1), 61-89.

Meyer, J. P., Allen, N.J. (1997). Commitment in the Worldplace Theory Reserch and Application. $2^{\text {Th }}$ Edition. Sage Publications. California.

Muhammad, E. Z. G, \& Mukzam, M. D. (2017). Pengaruh Budaya Organisasi Terhadap Kinerja Karyawan (Studi pada Karyawan Bank BRI Kantor Cabang Tuban). Jurnal Administrasi Bisnis (JAB), 53(1), 89-95.

Musabah, S, Zefeiti, B. A., \& Mohamad, N. A. (2017). The influence of organizational commitment on Omani public employees' work performance. International Review of Management and Marketing, 7(2), 151-160.

Nasir, N., Halimatussakdiah, H., Suryani, I., Zuhra, S. E., Armia, S., \& Mahdani, M. (2019, January). How Intrinsic Motivation and Innovative Work Behavior Affect Job Performance. Advances in Social Science, Education and Humanities Research 292(1), 606-612).

Newstrom. J. W, \& Keith, D. (2002). Organizational behavior. $11^{\text {Th }}$ Edition. McGraw-Hill Book Co. USA.

OECD. (2018). Oslo Manual (2018: Proposed Guidelines for Collecting and Interpreting Technological Innovation Data. revised edition. Eurostat. Paris.

Organ. D. W. (1988). Organizational Citizenship Behavior: The good soldier syndrome. $1^{\text {Th }}$ Edition. Lexington Books. Lexington.

Ornek, A. S., \& Ayas, S. (2015). The relationship between intellectual capital, innovative work behavior and business performance reflection. Procedia - Social and Behavioral Sciences 195, 1387-1395.

Ortiz. M. Z, E. Rosario, E. Marquez, \& P. C. Gruneiro. (2015). Relationship between organizational commitment and organizational citizenship behaviour in a sample of private banking employee. International Journal of Sociology and Social Policy, 35(1/2), 91-106.

Peraturan Bank Indonesia Nomor 14 Tahun (2012) Penilaian Kualitas Aset Bank Umum. 24 Oktober (2012). Lembaran Negara Republik Indonesia Tahun (2012 Nomor (202. Jakarta.

Pervaiz. K. A, \& C. D. Shepherd. (2010). Innovation Management. $1^{\text {st }}$ ed., Pearson Education, Inc. New Jersey.

Pranita F. M. (2017). Influence of motivation and organizational commitment on work satisfaction and employee performance. Proceeding of ICECRS. 24-25 November: 24-31.

Pristiyono, A. P. Nasution, S. L. Nasution, R. Watrianthos, \& Triyanto, Y. (2019). Path analysis of work intervening variables. International Journal of Scientific \& Technology Research, 8(8), 1134-1136. 
Purba, S. (2009). Pengaruh Budaya Organisasi, Modal Intelektual, \& Perilaku Inovatif Terhadap Kinerja Pemimpin Jurusan Di Universitas Negeri Medan. Jurnal Kinerja, 5(2), 150-167.

Porter, L. W., Steers, R. M., Mowday, R. T., \& Boulian, P. V. (1974). Organizational commitment, job satisfaction, and turnover among psychiatric technicians. Journal of applied psychology, 59(5), 603.

Rahayu, E. S. (2017). Pengaruh Komitmen Organisasi Terhadap Organizational Citizenship Behavior Dan Kinerja Karyawan (Studi pada Karyawan Medik Rumah Sakit Fathma Medika Gresik). Jurnal Administrasi Bisnis, 52(1), 138-145.

Rauf, F.H.A. (2016). Two sides of the same coin: Harmful or helpful? A critical review of the consequences of organizational citizenship behavior. International Journal of Business and Management Review, 4(2), 60-77.

Renyut, B. C, Modding, H. B., Bima, J., \& Sukmawati, S. (2017). The effect of organizational commitment, competence on Job satisfaction and employees performance in Maluku Governor's Office. IOSR Journal of Business and Management (IOSR-JBM), 19(11), $18-29$.

Robert, K., \& Kinicki, A. (2005). Perilaku Organisasi. Buku 2 Edisi 5, Salemba Empat, Jakarta.

Sari. S. A. (2016). Pengaruh Budaya Organisasi Terhadap Kinerja Karyawan Melalui Organizational Citizenship Behaviour Sebagai Variabel Intervening. Jurnal Ilmu Manajemen UNESA, 4(3), 285-301.

Shaputra, A. R., \& Hendriani, S. (2015). Pengaruh kompetensi, komitmen dan pengembangan karir terhadap kinerja karyawan PT. Bank Rakyat Indonesia (Persero) Kantor Wilayah Pekanbaru. Jurnal Tepak Manajemen Bisnis 7(1), 1-21.

Singh, S. S., Sharma, S., Keswani, \& Singh, P. (2016). Measuring Impact Of Organizational Citizenship Behavior On Firm Performance In Indian Banking Industry: An Empirical Analysis. International Conference on Management, Economics and Social Sciences. 19-20 November: $35-42$.

Steers, R.M., \& Porter, L.W. (1991). Motivation and Work Behavior. 5th Ed. McGraw - Hill Book Co. USA.

Stoffers J. M, \& Heijden, B.V. (2009). Towards an HRM Model predicting Organisational Performance by Enhancing Innovative Work Behaviour: A Study among Dutch SMEs in the Province of Limburg. Business Leadership Review, 70(4), 1-13.

Sugianingrat. A. P. W, R. E. Sapta, A. D. C. Carla, X. Mateuw, D. R. P. Salustiano, \& G. S. Wayan. (2019). The employee engagement and OCB as mediating on employee performance. International Journal of Productivity and Performance Management, 68(2), $319-339$.

Sugiyono. (2016). Metode Penelitian Kuantitatif, Kualitatif, \& R\&D. Edisi 1. Alfabeta. Bandung.

Sutopo. J. (2018). Effect of budget participation, organizational commitment, work satisfaction, job relevant information, organizational culture and locus of control on performance of employees financial part of education division regency of Klaten. Advance Journal, 5(1), 54-61.

Sutrisno, A., Haryono, T., \& Warso, M. (2018). Pengaruh Kepuasan Kerja Dan Komitmen Organisasi Terhadap Kinerja Karyawan Melalui Organizational Citizenship Behavior Sebagai Variabel Intervening. Journal of Management, 4(4), 34-57.

Suwibawa. A, A. A. P. Agung, \& I. K. S. Sapta. (2018). Effect of organizational culture and organizational commitment to employee performance through organizational citizenship behavior (OCB) as Intervening Variables (Study on Bappeda Litbang Provinsi Bali). International Journal of Contemporary Research and Review, 9(08), (20997-21013).

Syauta. J. H, Troena, E. A., Setiawan, M., \& Solimun. (2012). The influence of organizational culture, organizational commitment to job satisfaction and employee performance (Study at Municipal Waterworks of Jayapura, Papua Indonesia). International Journal of Business and Management Invention, 1(1), 69-76.

Taghipour, A., \& Dezfuli, Z. K. (2013). Innovative behaviors: Mediate mechanism of job attitudes. Procedia-Social and Behavioral Sciences 84(2013), 1617-1621.

Tsui, A. S., Pearce, J. L., Porter, L. W., \& Tripoli, A. M. (1997). Alternative approaches to the employee organization relationship: Does investment in employee pay off?. Academy of Management Journal, 40(5), 1089-1121

Uddin, M. A., Mahmood, M., \& Fan, L. (2018). Why individual employee engagement matters for team performance? Mediating effect of employee commitment. Team Performance Management: An International Journal, 25(1/2), 47-68.

Naranjo-Valencia, J. C., Jiménez-Jiménez, D., \& Sanz-Valle, R. (2011). Innovation or imitation? The role of organizational culture. Management decision. Manajemen Decesion 49(1), 997-1015).

Valle, R. S, Valencia, J. C. N., Dijemez, D. J., \& Caballlero, L.P. (2011). Linking Organizational Learning With Technical Innovation And Organizational Culture. Journal of Knowledge Management, 15(6), 997-1015).

Wagiman, S. (2018). Pengaruh Budaya Organisasi, Komitmen Organisasi Dan Kepuasan Kerja Terhadap Kinerja Karyawan. Prosiding SENDI_U (2018, 25 Juli: 566-574.

Wirawan. (2017). Kepemimpinan: teori, psikologi, perilaku organisasi, aplikasi dan penelitian. Edisi 1. PT. Raja Grafindo Persada. Jakarta.

Wu, L. F., Huang, I. C., Huang, W. C., \& Du, P.L. (2019). Aligning organizational culture and operations strategy to improve innovation outcomes: An integrated perspective in organizational management. Journal of Organizational Change Management, 2(1), $133-149$.

Yaseen, A., Liaquat, M., Hasan, I. E., \& Hasan, M. U. (2015). Impact of organizational culture and social influence on organizational citizenship behaviour with mediating effect of interactional justice. Sci. Int. Lahore, 27(3), 2443-2450.

Yiing, L. H., \& Ahmad, K. Z. (2009). The moderating effects of organizational culture on the relationships between leadership behaviour and organizational commitment and between organizational commitment and job satisfaction and performance. Journal of Productivity and Performance Management, 63(2), 308-323.

Yuan, F., \& Woodman, R. W. (2010). Innovative behaviour in the workplace: the role of performance and image outcome expectations. Academy of Management Journal, 53(2), 323-342.

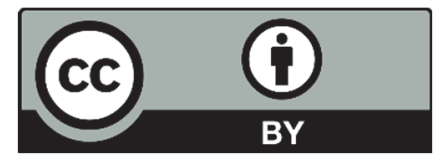

(C) 2020 by the authors; licensee Growing Science, Canada. This is an open access article distributed under the terms and conditions of the Creative Commons Attribution (CC-BY) license (http://creativecommons.org/licenses/by/4.0/). 